\title{
Synchronized anthesis and predation on pollen in the marine angiosperm Thalassia testudinum (Hydrocharitaceae)
}

\author{
Brigitta I. van Tussenbroek ${ }^{1, *}$, J. G. Ricardo Wong $^{2}$, Judith Márquez-Guzman ${ }^{2}$ \\ ${ }^{1}$ Unidad Académica Puerto Morelos, Instituto de Ciencias del Mar y Limnología, \\ Universidad Nacional Autónoma de México, Apdo. Postal 1152, Cancún, 77500 Quintana Roo, Mexico \\ ${ }^{2}$ Facultad de Ciencias, Universidad Nacional Autónoma de México Laboratorio del Desarrollo en Plantas, Circuito Exterior, \\ Ciudad Universitaria, Del. Coyoacán, México D.F. 04510, Mexico
}

\begin{abstract}
Synchrony in the anthesis of male and female flowers of the hydrophilous dioecious marine angiosperm Thalassia testudinum was studied by following flower buds of 64 staminate and 34 carpellate flowers in situ during night and day to observe the timing of flower opening. Anthesis of female flowers occurred throughout the day, with a slight peak between 15:00 and 17:00 h. The time lapse between initiation of anthesis and full opening of the flowers was $\sim 2$ to $3 \mathrm{~h}$. Anthesis in male flowers was highly synchronized, and all ripe primordia initiated anthesis within $1 \mathrm{~h}$ at dusk at $\sim$ 18:00 $\mathrm{h}$, and pollen was released within 1 to $2 \mathrm{~h}$. Male flowers in anthesis, or briefly after anthesis, were a targeted food source for herbivorous fish and $>30 \%$ of the staminate flowers were consumed during our observations. The highly synchronized nocturnal pollen release is unusual for an abiotic pollinator, and we hypothesize that this may be a mechanism to ensure fertilization or, alternatively, may be a reponse to avoid pollen predation by fish.
\end{abstract}

KEY WORDS: Seagrass $\cdot$ Hydrophilous pollination $\cdot$ Synchronization $\cdot$ Fish $\cdot$ Scaridae $\cdot$ Caribbean Sea

Resale or republication not permitted without written consent of the publisher

\section{INTRODUCTION}

There are 59 species of seagrasses (Green \& Short 2003), which complete their entire life-cycle in the marine environment. All species but one (Enhalus acoroides [L.f] Royle) have mechanisms of submersed pollination (hyphydrophily; Ackerman 2006). The evolution of hydrophily required adaptations in originally terrestrial floral morphology (Sculthorpe 1985, Kuo \& McComb 1989). Floral structures of seagrasses generally have reduced petals, or lack a perianth altogether. Pollen is either filiform, or consists of spheroidal pollen grains embedded in mucilaginous strands (Pettit 1984). Hydrophily is an abiotic mechanism of pollen transfer and therefore nondirectional; thus, much pollen never comes into contact with a stigma of the same species (Barrett et al. 1993). In addition, most seagrasses are dioecious, and separation of sexes increases variance in reproductive success (Wilson \& Harder 2003). A possi- ble mechanism to maximize probability of fertilization, in addition to excess production of pollen (Ackerman 2006), may be synchronization of the anthesis of male and female flowers. In the marine environment, synchronous release of gametes is common and is thought to result in high fertilization levels. An impressive example of the latter is the synchronized mass spawning of the algae in the order Bryopsidales (Clifton 1997). Various species of seagrasses growing in the intertidal zone have synchronized staminate flower anthesis with low tides when the pollen masses are transported to the stigmas of the pistillate flowers on the water surface (Cox 1991). However, much less is known about the anthesis of subtidal seagrasses. Turtlegrass Thalassia testudinum Banks ex König (Hydrocharitaceae), the dominant seagrass species in the Gulf of Mexico and Caribbean Sea, rarely grows intertidally and is usually found at depths between 0.3 and $5.0 \mathrm{~m}$. It is dioecious, and male inflorescences tend to be more abundant than 
female flowers (van Tussenbroek et al. 2006). The pollen grains of $T$. testudinum are spherical, 56 $\mu \mathrm{m}$ in diameter, and are released (by means of longitudinal slits in the anthers) in strands of mucilage matrix, which are slightly negatively buoyant (Cox \& Tomlinson 1988). Nocturnal anthesis of male flowers was noted by Cox \& Tomlinson (1988), but they did not present quantitative data. Synchronized opening of flowers at dusk is not uncommon in terrestrial angiosperms, where it has been associated with nocturnal pollinators such as moths, bats, or beetles (Gribel et al. 1999, Miyake \& Yahara 1999), but as far as we know, it has never been reported before for abiotically pollinated plants (pollen transfer by wind or water).

During a previous attempt to examine in situ the sequence of anthesis of a male flower of Thalassia testudinum, we filmed a juvenile parrotfish bite the dehisced stamen, and return twice to consume leftovers. This observation was surprising, because during our at least twice a month field trips for $>15$ yr during daylight in the reef lagoon, we had never observed parrotfish grazing on dehiscent male or female flowers. The purpose of the present study was 2-fold: (1) to determine if anthesis of male and female flowers occurs simultaneously, and whether pollination is synchronized with light regimes; and (2) to establish whether parrotfish prey upon young stages of male and female flowers.

\section{MATERIALS AND METHODS}

The study was carried out in Puerto Morelos reef lagoon, Mexico $\left(20^{\circ} 51^{\prime} \mathrm{N}, 86^{\circ} 55^{\prime} \mathrm{W}\right)$, which is bordered on the seaward side by a fringing reef. Terrestrial influence is virtually absent because of the lack of surface rivers, and salinity is 35.7 psu (Ruíz-Rentería et al. 1998). Monthly mean surface water temperatures vary between $\sim 25^{\circ} \mathrm{C}$ in the winter and $\sim 31^{\circ} \mathrm{C}$ in the summer (Ruíz-Rentería et al. 1998). A well-developed seagrass community dominated by Thalassia testudinum covers the coarse calcareous sands in this reef lagoon. Flowering frequency of this seagrass varies throughout the reef lagoon, generally being low in near-coastal and mid-lagoon areas, and higher near the reef (ca. 20 to $30 \%$ of the shoots produce flowers; van Tussenbroek 1994).

Nomenclature of the structures of the inflorescences of Thalassia testudinum follows Tomlinson (1969) and Orpurt \& Boral (1964). Inflorescences grow in the leaf axils; the male flowers occur in clusters of 1 to 5 (usually 3), and consist of a peduncle with a spathe covering early-stage primordia, 3 tepals and 8 to 13 stamen (usually 9 to 12). The female flowers usually occur singly and consist of a long peduncle, with 3 tepals and
12 to 18 stigmas (usually 14 ). At the base of the peduncle, well below sediment level, a separate spathe covers the inferior ovary. The primordia of both staminate and pistillate flowers are situated below the sediment until maturity is reached, when they are raised a few $\mathrm{cm}$ above the level the level of the substrate, in between the strap-like leaves.

During the reproductive season in May 2004, a site with a high incidence of flowering in the back-reef area of Puerto Morelos reef lagoon was selected for this study. The depth was $3.8 \mathrm{~m}$ and distance from the studied flowers to the reef was $\sim 40 \mathrm{~m}$. Based on prior field observations, 3 phases of anthesis of male flowers were established: (1) bud, which consists of a closed primordium, the tepals fully covering the stamen (Fig. 1A); (2) anthesis, at which the tepals are opening (thus exposing the stamen), and followed by dehiscence of the anthers and pollen release: this phase lasts for approximately 1 to $2 \mathrm{~h}$ (Fig. 1B-D); and (3) postanthesis, which is often the phase referred to as the male flower, at which the dehisced stamen is in an almost horizontal position, but with residuals of mucilage substance with pollen that remain attached to the anthers until the following day (Fig. 1E,F). On the afternoon of May 17, 2004, between 13:00 and 16:00 h, 40 male buds, situated well above or just above the substratum, were marked with a galvanized nail and a numbered ribbon. The nails were joined with a thin cord, to allow the divers to locate the individual flowers during the night. The flowers were monitored at intervals of $2 \mathrm{~h}$, until 06:00 h on May 18. At each observation, the phase of anthesis was recorded for each flower. Three buds remained closed, and they were included in the subsequent trial. For a second series of observations on male anthesis, 37 new buds were marked between 06:00 and 08:00 $\mathrm{h}$ in the morning of May 18, and they were followed during daylight hours until the morning of May 19. In contrast to those marked previously, these newly marked buds were not clearly visible, but were situated just at sediment level and completely covered by the spathes. The observation procedure was as described above, but an additional phase of stretched bud was included. This stretched bud phase describes rapid elongation of the pedicel, through which the bud becomes raised 1 to $2 \mathrm{~cm}$ above the substratum, whereas the spathe, which until then covered the primordium, remains at sediment level.

Female flower buds $(\mathrm{N}=37)$ were marked on May 24, 2004, and followed until the morning of May 26. In analogy with the male flowers, 3 phases were distinguished: (1) bud, which consists of a closed primordium, the tepals fully covering the stigmas (Fig. 1H); (2) anthesis, at which time the tepals are opening, exposing the stigmas still in vertical position; 
and (3) post-anthesis, which showed lively greencoloured stigmas, in a more or less horizontal position (Fig. 1I). The transition between Phases 2 and 3 lasted longer than that of the male flowers, with an estimated duration of 2 to $3 \mathrm{~h}$.
Flowers lost during the above-mentioned observations on anthesis were verified to check whether they exhibited typical bite marks of fish, showing a neatly cut pedicel that lacked remains of stamen or tepals (Fig. 1G).
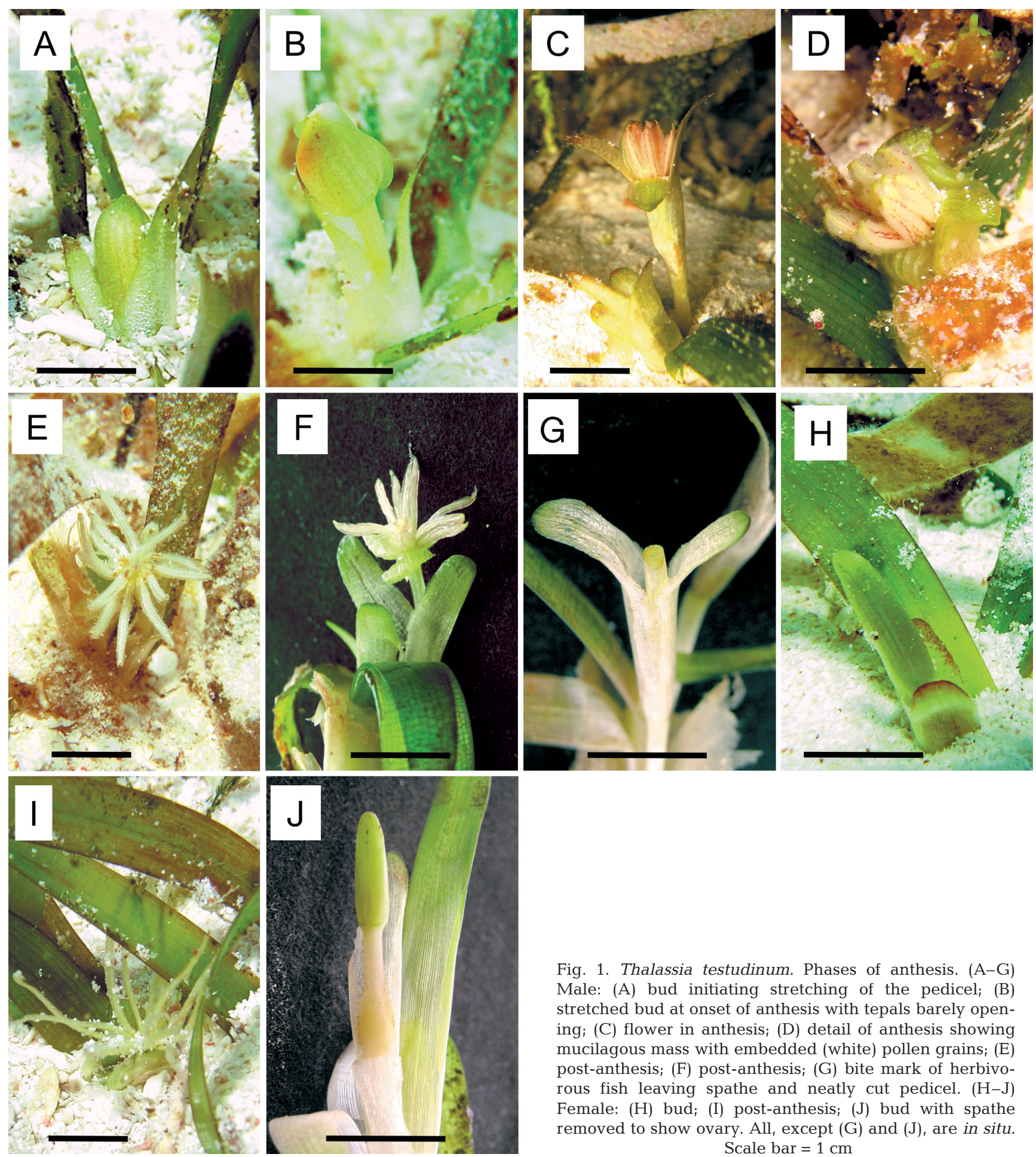

Fig. 1. Thalassia testudinum. Phases of anthesis. (A-G) Male: (A) bud initiating stretching of the pedicel; (B) stretched bud at onset of anthesis with tepals barely opening; (C) flower in anthesis; (D) detail of anthesis showing mucilagous mass with embedded (white) pollen grains; (E) post-anthesis; (F) post-anthesis; (G) bite mark of herbivorous fish leaving spathe and neatly cut pedicel. (H-J) Female: (H) bud; (I) post-anthesis; (J) bud with spathe removed to show ovary. All, except $(\mathrm{G})$ and $(\mathrm{J})$, are in situ. 


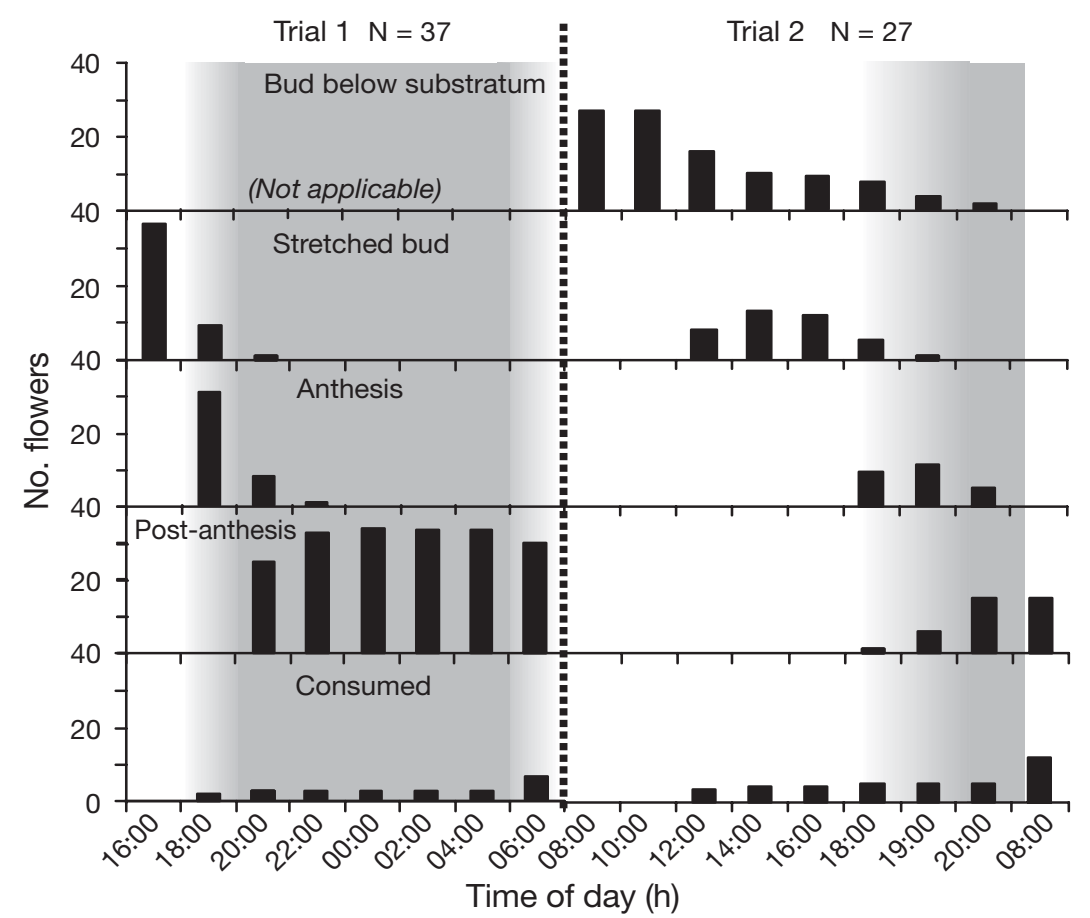

Fig. 2. Thalassia testudinum. Anthesis of male flowers in Puerto Morelos reef lagoon. Trial 1: nighttime trial initiated late afternoon on May 17, 2004. Trial 2: daytime trial initiated early morning on May 18, 2004. $\mathrm{N}=40$ for both trials; however, buds which remained closed were excluded ( 3 in Trial 1 and 13 in Trial 2). Grey shading represents twilight and nocturnal hours. Bars: number of flowers in each phase of anthesis as described for male flowers in 'Materials and methods'
18:00 and 19:00 h, and most had released their pollen by 20:00 h. At 08:00 $\mathrm{h}$ the following morning, 13 flowers had not opened, 15 were in the post-anthesis phase showing the recently dehisced stamen, and 12 flowers had been consumed (Fig. 2). In contrast to male flowers, the anthesis of female flowers occurred throughout the day, with peak hours between 15:00 and 17:00 h (Fig. 3). Of the 37 marked female flowers, 3 buds remained closed and were excluded from the analysis. Only 1 female dehisced flower had a bite mark in the stigmas, which were neatly cut but were not consumed completely.

\section{DISCUSSION}

Herbivore pressure on the young stages of staminate flowers of Thalassia testudinum in our study area was considerable. In total, 64 male flowers dehisced and $>30 \%$ of these flowers were lost to herbivory. During a complete 24 h cycle, 5 of the 27 stretched, unopened buds (9\%) were consumed,

\section{RESULTS}

Observations on the staminate buds marked on May 16, 2004, showed that 26 of the 40 marked buds had initiated anthesis between 16:00 and 18:00 h, and 2 buds had been eaten. Between 18:00 and 20:00 h, another 8 buds had opened, and another one was consumed (Fig. 2). In total, 7 male flowers (as buds or in post-anthesis) were lost during the evening and morning twilight hours, all showing a neatly cut-off pedicel (Fig. 1G), indicating that they were consumed by fish. Of these 40 marked staminate buds, 3 remained closed until the end of the trial on the following day and were excluded from further analysis. During the May 18 daylight observations of 40 newly marked male buds, various primordia had initiated stretching at noon, which continued until 14:00 h. All the stretched buds dehisced between

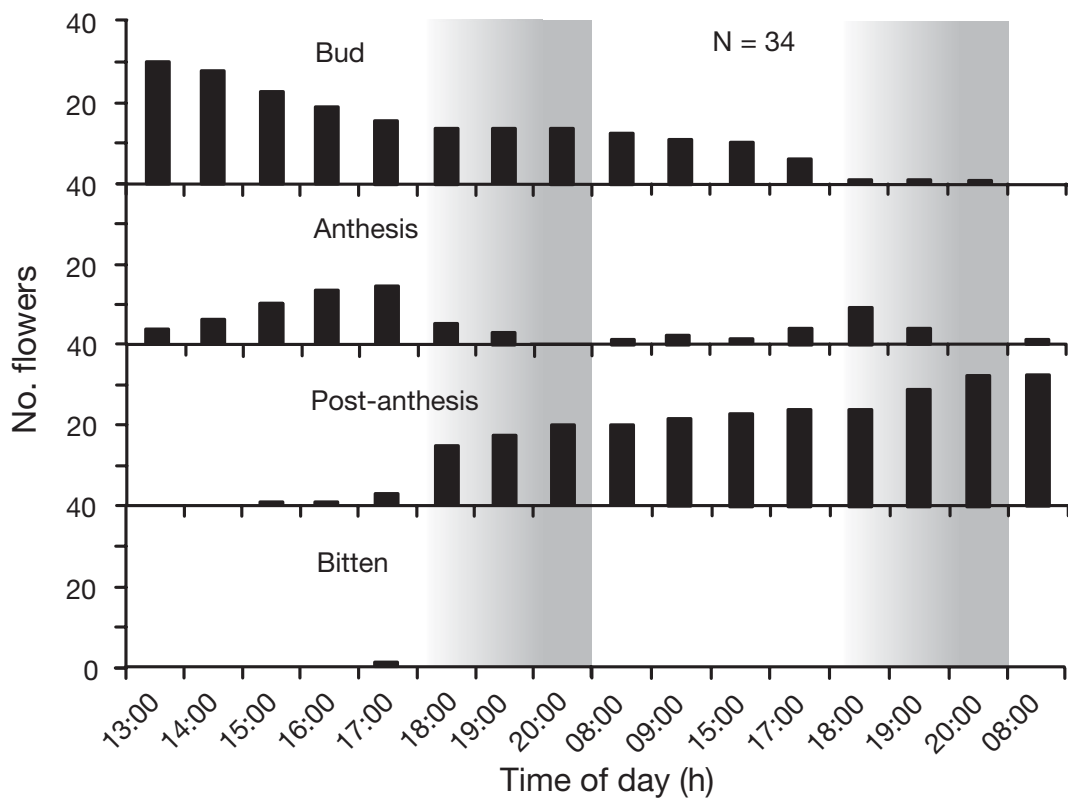

Fig. 3. Thalassia testudinum. Phases of anthesis of 34 female flowers in Puerto Morelos reef lagoon on May 24 to 26, 2004. $\mathrm{N}=37$, but 3 buds that did not open are excluded. Grey shading represents twilight and nocturnal hours. Bars: number of flowers in each phase of anthesis as described for female flowers in 'Materials and methods' 
and another 7 male flowers in the post-anthesis stage $(25 \%)$ were eaten the following morning. The 13 marked, closed buds were not touched by the fish. Pollen grains of the only other Thalassia species ( $T$. hemprichii) have high protein and sugar contents (Pettitt 1981), and thus may be an attractive food source. After dehiscence of the anthers, residuals of the mucilage matrix with pollen remained attached to the stamen, perhaps in sufficient quantity to attract the herbivores. In contrast, none of the 34 young dehiscent female flowers was lost, and only one had a bite-mark in the stigmas, suggesting that the fish rejected this food source. The stigmas most likely do not contain constituents of nutritive value, and the ovaries, which may contain more valuable reserves, are situated below the sediments (Fig 1J). We observed a juvenile specimen of Sparisoma viride consuming a male flower; this and other species of parrotfish (family Scaridae) are common herbivores on the leaves of Thalassia testudinum (Valentine \& Heck 1999), especially in seagrass habitats adjoining reefs, where fish show diurnal migrations from the reefs to forage over the seagrass beds (Randall 1965, Weinstein \& Heck 1979, Tribble 1981). This is the first report on fish predation on pollen, but fish have been reported to consume fruits or seeds of Posidonia oceanica (Piazzi et al. 2000), Posidonia australis (Orth et al. 2002) and Zostera marina (Adams 1976). Pollen grains of terrestrial plants have a well-developed exine coat which is highly resistant to degradation by digestive enzymes, and extraction efficiencies of their contents by pollen depredators varies widely (between 7 and $100 \%$, Herrera \& Martínez del Río 1998 and references therein). The exine coat of Thalassia spp. pollen is poorly developed (Pettitt 1981, R. Wong unpubl. data), and the feeding efficiency of the fish may be high, though further studies are required. It is unlikely that the fish aid in the dispersal of the pollen, but they may have a negative effect on reproductive success in reducing male flower density. Reusch (2003) experimentally reduced the floral densities of the monoecious temperate seagrass Zostera marina and found that seed set was reduced. Thus, in the case of $T$. testudinum, it is possible that the reduction in male flower density due to excessive herbivory may cause pollen limitation (sensu Knight et al. 2005).

Anthesis of Thalassia testudinum staminate flowers at Puerto Morelos was highly synchronized, and occurred at dusk and during the night, which confirmed the observation of Cox \& Tomlinson (1988). Nocturnal anthesis, until date, has not been registered for other hydrophilous or anemophilous plants, and for terrestrial angiosperms it has been associated exclusively with nocturnally active pollinators (Gribel et al. 1999, Miyake \& Yahara 1999). In the case of T. tes- tudinum, it is possible that the chance of pollen encountering a receptive stigma is highest at the end of the day, because female flowers only open during daylight. Thus, T. testudinum may show a certain degree of synchrony between the male and female reproductive structures to enhance fertilization, analogous to the synchronized bouts of male and female gamete release registered for various externally fertilizing marine fauna (Levitan \& Petersen 1995) and macro-algae (Brawley \& Johnson 1992, Clifton 1997). An alternative explanation for synchronized male anthesis at dusk may be avoidance of herbivory by fish. Cox \& Tomlinson (1988) suggested that it would be of interest to study whether there is a connection between the timing of anthesis of $T$. testudinum and predation on the pollen. Bruggemann et al. (1994) reported that the herbivorous fish Sparisoma viride was only active by day, and that feeding activity ( \pm range) stopped $16 \pm 8 \mathrm{~min}$ after sunset, which roughly coincided with the time of the onset of male flower anthesis of $T$. testudinum. Grazing on flowers that have not released their pollen may result in pollen limitation (see above), and constitute a sufficiently strong selection pressure to have evolved mechanisms of reproductive assurance, such as flowering at dusk after cessation of herbivore activity. Seagrasses and fish have evolved together since angiosperms invaded the marine environment during the Cretaceous or Eocene periods (Den Hartog \& Kuo 2006), and it is likely that fish have exerted strong selective forces on the evolution of the flowers of at least some seagrass species. The observation that the male buds of $T$. testudinum remained below the substratum until several hours before pollen release maybe also be an avoidance mechanism to reduce the duration of exposure to predators.

Experimental research into the reproductive ecology of Thalassia testudinum and future observations on other seagrasses may verify whether synchronization of hydrophilous plants is more common, and shed light on the mechanisms underlying such synchronization.

Acknowledgements. The authors thank the diving team: F. Negrete, C. Barradas, D. Gasca, J. K. van Dijk, and X. Hernandez. M. Weiss and E. Lozano kindly loaned their underwater video and recording system.

\section{LITERATURE CITED}

Ackerman JD (2006) Sexual reproduction of seagrasses: pollination in the marine context. In: Larkum AWD, Orth RJ, Duarte CM (eds) Seagrasses: biology, ecology and conservation. Springer, Dordrecht, p 98-109

Adams SM (1976) Feeding ecology of eelgrass fish communities. Trans Am Fish Soc 105:514-519

Barrett SCH, Eckert CG, Husband BC (1993) Evolutionary 
processes in aquatic plant populations. Aquat Bot 44: 105-145

Brawley SH, Johnson LE (1992) Gametogenesis, gametes and zygotes: an ecological perspective on sexual reproduction in the algae. Br Phycol J 27:233-252

Bruggemann JH, van Oppen MJH, Breeman AM (1994) Foraging by the stoplight parrotfish Sparisoma viride. II. Intake and assimilation of food, protein and energy. Mar Ecol Prog Ser 106:57-71

Clifton KE (1997) Mass spawning by green algae on coral reefs. Science 275:1116-1118

Cox PA (1991) Abiotic pollination: an evolutionary escape for animal-pollinated angiosperms. Phil Trans R Soc Lond B Biol Sci 133:217-224

Cox PA, Tomlinson PB (1988) Pollination ecology of seagrass, Thalassia testudinum (Hydrocharitaceae), in St. Croix. Am J Bot 75:958-965

Den Hartog C, Kuo J (2006) Taxonomy and biogeography of seagrasses. In: Larkum AWD, Orth RJ, Duarte CM (eds) Seagrasses: biology, ecology and conservation. Springer, Dordrecht, p 1-23

Green EP, Short FT (2003) World atlas of seagrasses. Present status and future conservation. University of California Press, Berkeley, CA

Gribel R, Gibbs PE, Queiróz AL (1999) Flowering phenology and pollination biology of Ceiba pentandra (Bombacaceae) in central Amazonia. J Trop Ecol 15:247-263

Herrera MLG, Martínez del Río C (1998) Pollen digestion by New World bats: effects of processing time and feeding habits. Ecology 79:2828-2838

Knight TM, Steets JA, Vamosi JC, Mazer SJ and others (2005) Pollen limitation of plant reproduction: pattern and process. Annu Rev Ecol Evol Syst 36:467-497

Kuo J, McComb AJ (1989) Seagrass taxonomy, structure and development. In: Larkum AWD, McComb AJ, Shepherd SA (eds) Biology of seagrasses: a treatise on the biology of seagrasses with special reference to the Australian region. Elsevier, Amsterdam, p 6-73

Levitan DR, Petersen C (1995) Sperm limitation in the sea. Trends Ecol Evol 10:228-231

Miyake T, Yahara T (1999) Theoretical evaluation of pollen transfer by nocturnal and diurnal pollinators: when should a flower open? Oikos 86:233-240

Orpurt PA, Boral LL (1964) The flowers, fruits and seeds of Thalassia testudinum König. Bull Mar Sci Gulf Caribb 14: 296-302

Orth RJ, Heck KL Jr, Tunbridge DJ (2002) Predation on seeds of the seagrass Posidonia australis in Western Australia.

Editorial responsibility: Kenneth Heck,

Dauphin Island, Alabama, USA
Mar Ecol Prog Ser 244:81-88

Pettitt JM (1981) Reproduction in seagrasses: Pollen development in Thalassia hemprichii, Halophila stipulacea and Thalassodendron ciliatum. Ann Bot 48:609-622

Pettitt JM (1984) Aspects of flowering and pollination in marine angiosperms. Oceanogr Mar Biol Annu Rev 22: 315-342

Piazzi L, Balestri E, Cinelli F (2000) Grazing of inflorescences of the seagrass Posidonia oceanica (L.) Delile. Bot Mar 43:581-584

Randall JE (1965) Grazing effect on seagrasses by herbivorous reef fishes in the West Indies. Ecology 46:255-260

Reusch TBH (2003) Floral neighbourhoods in the sea: how floral density, opportunity for outcrossing and population fragmentation affect seed set in Zostera marina. J Ecol 91: 610-615

Ruíz-Rentería F, van Tussenbroek BI, Jordán-Dahlgren E (1998) Puerto Morelos, Quintana Roo, Mexico. In: Kjerfve B (ed) CARICOMP-Caribbean coral reef, seagrass and mangrove sites. UNESCO, Paris, p 57-66

Sculthorpe CD (1985) The biology of aquatic vascular plants. Edward Arnold, London. Reprint ed, Koeltz Scientific Books, Königstein

Tomlinson PB (1969) On the morphology and anatomy of turtle grass, Thalassia testudinum (Hydrocharitaceae). III. Floral morphology and anatomy. Bull Mar Sci 19:57-71

> Tribble GW (1981) Reef-based herbivores and the distribution of two seagrasses (Syringodium filiforme and Thalassia testudinum) in the San Blas Islands (western Caribbean). Mar Biol 65:277-281

Valentine JF, Heck KL Jr (1999) Seagrass herbivory: evidence for the continued grazing of marine grasses. Mar Ecol Prog Ser 176:291-302

van Tussenbroek BI (1994) Aspects of the reproductive ecology of Thalassia testudium in Puerto Morelos reef lagoon, Mexico. Bot Mar 37:413-419

van Tussenbroek BI, Vonk JA, Stapel J, Erftemeijer PLA, Middelburg JJ, Zieman JC (2006). The biology of Thalassia. Paradigms and recent advances in research. In: Larkum AWD, Orth, RJ, Duarte CM (eds) Seagrasses: biology, ecology and conservation. Springer, Dordrecht, p 409-439

Weinstein MP, Heck KL Jr (1979) Ichthyofauna of seagrass meadows along the Caribbean coast of Panama and the Gulf of Mexico: composition, structure and community ecology. Mar Biol 50:97-107

Wilson WG, Harder LD (2003) Reproductive uncertainity and the relative competitiveness of simultaneous hermaphroditism versus dioecy. Am Nat 162:220-241

Submitted: September 18, 2006; Accepted: August 15, 2007

Proofs received from author(s): January 17, 2008 